3Iranian Journal of Pathology | ISSN: 2345-3656

\title{
Current Diagnostic Status of Pheochromocytomaand Future Perspective: A Mini Review
}

\author{
Fatemeh Khatami $^{1}$, Seyed Mohammad Tavangar ${ }^{2 *}$
}

1. Chronic Diseases Research Center, Endocrinology and Metabolism Population Sciences Institute, Tehran University of Medical Sciences, Tehran, Iran

2. Dept. of Pathology, Dr. Shariati Hospital, Tehran University of Medical Sciences, Tehran, Iran

\section{KEYWORDS}

Pheochromocytomas(PCCs)

Histopathology

Genes

Catecholamines

Metanephrines

Article Info

Received 11 Jun 2017;

Accepted 04 Jul 2017;

Published Online 01 Jul 2017;

\begin{abstract}
Pheochromocytomas (PCCs) are rare neuroendocrine tumors. The current diagnostic tools are based on biochemistry and histopathology results, but heterogeneity of diagnostic markers, signs and symptoms of PCCs bring a lot of difficulties for these two current methods. Unfortunately, microscopic understanding of PCCs is not adequate for its confident prognosis and management. There are data linking specific genotypes of PCCs tumors to specific locations, typical biochemical phenotypes or future clinical behaviors. The detection of a germ-line mutation possibly can guide us to an early diagnosis, appropriate treatment, and regular surveillance with better prognosis for patients but also and their family members. Moreover, the latest discoveries in gene sequencing, circulating DNA (ctDNA) and circulating tumor cells (CTCs) will support the exact molecular pathogenesis of PCCs to provide an important basis for future PCCs managements.
\end{abstract}

Corresponding Information: Dr. Seyed Mohammad Tavangar, Dept. of Pathology, Dr. Shariati Hospital, Tehran University of Medical Sciences, Tehran, Iran, Tel: +98 21 84902187, Fax: +98 21 88633078, E-mail address: Tavangar@ams.ac.ir

Copyright $\odot$ 2017, IRANIAN JOURNAL OF PATHOLOGY. This is an open-access article distributed under the terms of the Creative Commons Attribution-noncommercial 4.0 International License which permits copy and redistribute the material just in noncommercial usages, provided the original work is properly cited.

\section{Introduction}

Pheochromocytomas (PCCs) are infrequent, catecholamine-secreting, neuroendocrine tumors originated from chromaffin cells of the adrenal medulla (1). The annual incidence rate of pheochromocytoma is estimated around 0.8 per 100,000 person-years (2-4). Even though pheochromocytom may happen at any age, they are most widespread in the fourth to fifth decade (5). PCCs symptoms are diaphoresis, headache, sweating, palpitations, and cardiovascular problem such as myocardial infarctions, cardiomyopathy, and stroke (6). In spite of the fact that PCCs is associated with catecholamines increase in the circulation, some patients do not have any symptoms, so the diagnosis of PCCs can be more complicated (7). Most tumors can be recognized easily by determining some exact clinicpathological features (8-12). Because of various clinical manifests of PCCs, timely and precise diagnosis is a problematic issue. In fact PCCs can happen at any age with equal distribution in male and female, however the age of patients may indicate to the tumor's catecholamine phenotype and some fundamental genetic mutations $(13,14)$. Usually patients with an established mutation or hereditary syndrome could occur at a younger age than those with sporadic disease, whereas epinephrine secreting tumors happen at a later age (15). PCCs in elderly patients are typically sporadic and may present without classic signs and symptoms. Instead, some unexpected critical illness like stroke, heart failure in absence of coronary artery or vascular disease, and ketoacidosis can be seen $(15,16)$. Some symptoms of orthostatic hypotension such as lightheadedness, pre-syncope and syncope may be in patients with predominantly epinephrine or dopamine secreting tumors (17).

Microscopic histological characteristics of some endocrine tumors including PCCs are not satisfactory for exact benign and malignant tumors discrimination (18-20). As a result of this variety in clinical signs improvements in diagnosis, localization, management, and treatment of PCCs is extremely required to understanding its genetics and biology. The present position of microscopic 
pathology in management of PCCs is restricted to diagnosis and documentation of tumor behavior that may be clues to malignant potential (21). It is anticipated that future roles will involve more definitive assessment of malignancy using genetic and epigenetic biomarkers, genotype-phenotype correlation, and discovery of target genes for personalized PCCs therapy.

\section{Biochemical Diagnosis of Pheochromocytoma}

Usually diagnosis of PCCs requires approval by several tests like biochemical evidence of excessive catecholamine production. The most common traditional test is urinary catecholamine levels, urinary catecholamine metabolites or plasma catecholamines measurements (22-25). Catecholamines are metabolised within chromaffin cells to metanephrines (i.e. norepinephrine to normetanephrine and epinephrine to metanephrine), and measurements of fractionated metanephrines in urine or plasma offer greater diagnostic sensitivity to measurements of the parent catecholamines (2629). Analysis of 24 hour urinary metanephrines and normetanephrines offer the greatest sensitivity and specificity and negative plasma free metanephrines can be excluded for PCCs (29). It was shown that basal plasma catecholamine levels were elevated in 81 of 87 (93\%) patients (30). Also, chromograninA concentrations in plasma have been found to be raised in PCCs patients (31), but its prognostic significance still under debate. Dopamine (DA) secretion has been suggested as a indicator of PCCs malignancy $(32,33)$. Moreover, increasing level of aromatic L-amino acid decarboxylase (ALAAD) has been shown frequently in malignant PCCs (30). The tumor can be localized anatomically by computed tomography (CT), magnetic resonance imaging (MRI) or Metaiodobenzylguanidine (MIBG) scanning after the diagnosis has been biochemically established.

Extraordinarily, some PCCs could be "silent", because they may produce inadequate amounts of catecholamines and therefore no typical symptoms and signs and no positive biochemical tests (34). Moreover, PCCs produce catecholamines episodically, so plasma concentrations or urinary excretion of catecholamines will not be abnormal (35). Therefore, biochemical testing of plasma or urinary catecholamines and urinary metabolites of catecholamines are not constantly reliable to prove the presence of a PCCs tumor (36-38). A developed biochemical test that suggests measurements of plasma free normetanephrine and metanephrine, offered some advantages for biochemical testing of PCCs but it has some weak points as well $(39,40)$.

\section{Current Roles of Pathology in Pheochromocytomas's Managements \\ Usually PCCs is a rounded, single mass with} distortions of the gland that can be surrounded by the cortex if the tumor is small, whereas recognition of an adrenal remnant is not easy with extremely large tumors $(41,42)$. The diameter of PCC tumors generally is 3 to $5 \mathrm{~cm}$ with a wide range from 1 to $10 \mathrm{~cm}$ or more. The tumor is graywhite to tan, tight circumscribed, and usually encapsulated in crosssectional view (43).Microscopically PCCs usually have a nesting or alveolar form with separate nests of cells ("zellballen"), or a mixture of both (44). The nuclei of the tumor cells possibly have pseudo inclusions, and also while the cytoplasm of PCCs cells stay often lightly basophilic and finely granular (45). The cytoplasm frequently has neurosecretory granules and infrequently melaninlike pigments $(46,47)$. In spite of the fact of weakness of histological features in exact determining of malignancy, there are some suggesting features that can be associated with malignancy like necrosis, vascular invasion, and extensive capsular invasion (44, 48-50). In 2002 the Adrenal Gland Scaled Score (PASS) was introduced by Thompson for discrimination between benign tumors from malignant ones (51). It contains high cellularity, cellular monotony, mitotic figures, extension into adipose tissue, vascular invasion, capsular invasion, profound nuclear pleomorphism, and nuclearhyperchromasia and so on (51).

Immunohistochemical (IHC) staining procedures available in most pathology laboratories are able to provide the essential characteristic of endocrine tumors including PCCs $(9,18,52-57)$. Adrenal medullary cells and their tumors display positivity for various neuroendocrine markers, such as chromogranin $\mathrm{A}$, major proteins in the neurosecretory granules of neuroendocrine cells and sympathetic nerves, that has the highest 
concentration in the adrenal medulla. Chromogranin A ( $\mathrm{CgA})$, a major constituent of the matrix of catecholamine-containing secretary granules, is the single most specific and reliable generic neuroendocrine marker which is used in pathology practice $(9,58)$. Another IHC marker is a membrane glycoprotein of presynaptic vesicles, synaptophysin, which is reactive in neuronal presynaptic vesicles of the brain, spinal cord, retina, neuromuscular junctions and small vesicles of adrenal medulla and pancreatic islets (59). In fact, antibody to synaptophysin exactly stains neuronal, adrenal and neuroepithelial tumors, including adrenal and extra _ adrenal PCCs, pancreatic islet cell tumors, carcinoid tumors, pituitary/parathyroid adenomas, and thyroid medullary carcinoma (60, 61). There are some other suggesting neural tumors markers such as neuron-specific enolase (NSE) which is a glycolytic isoenzyme, the neural cell adhesion molecule (NCAM/CD56), S100 protein positive sustentacular cells, a melanoma marker Melan A (MART-1, A103)(62-66).

\section{Genetics of Pheochromocytomas}

It is a common knowledge that genetic and epigenetic alterations of tumors can provide evidence for superior tumor managements (67-71). According to the latest findings, around one-third of PCCs tumors are supposed to be triggered by germline mutations in at least 10 genes (72). These genes include: Rearranged during transfection (RET) proto-oncogene, Von Hippel-Lindau disease tumor-suppressor gene

(VHL), neurofibromatosis type 1 tumorsuppressor gene (NF 1), genes encoding four succinate dehydrogenase complex (SDH)(7276),responsible enzyme for flavination of the SDHA subunit (SDH assembly factor 2 (SDHAF2)(77, 78), tumor-suppressor genes TMEM 127 and MAX(79-81). The specific linking genotypes of these genes and typical biochemical phenotypes or future clinical behavior have been suggested (82-84). On the other hand, clinical features, immunohistochemistry and catecholamine production could support the proper direction of genetic testing PCCs (85). More than these 10 genes there are some genes were reporting in connection with PCCs tumors, for example germ-line mutations of Kinsin family member $1 \mathrm{~B}$ gene (KIF1B, located on chromosome 1p36.22)(86). KIF1B has a crucial role in cell response to hypoxia angiogenesis because it encodes a protein that provokes apoptosis (87).

Regarding PCCs transcription profiles, two different groups of hereditary PCCs were identified including first cluster which has VHL and SDHx mutant tumors and the second cluster with RET and NF1 mutations $(88,89)$. VHL/SDHx transcription profile is linked to the angiogenesis, hypoxia and a reduced oxidative response through stabilizing HIF-a that is a transcription factor with important role in apoptosis, angiogenesis, energy metabolism, proliferation, migration and invasion of tumor cells(87, 88).RET/NF1 cluster cover genes concerned in initiation of translation, protein synthesis and kinase signaling $(90)$ and is linked to the activation of the RAS/RAF/MAPK pathway and the PI3/AKT signaling pathway(87). Malignant PCCs is associated mostly with SDHB germ-line mutations $(82,83,91)$. In fact, mutation of RET, VHL,

NF1, TMEM-127 or MAX genes can suggest the intra-adrenal location of tumors (80, 92-94).

And intra-adrenal tumors have been infrequently detected in germ-line mutations of SDHD, SDHA and SDHC (88, 94, 95). Bilateral PCCs have been typically associated with RET, VHL, TMEM-127 and MAX mutations (7, 96, 97). After diagnosis of extra-adrenal tumors, the germline mutations can be found mainly in SDHx genes $(96,98,99)$. Extra-adrenal sympathetic tumors are generally linked to SDHB (particularly solitary, large tumors), less often to SDHD, rarely to SDHC and SDHA mutations $(95,100)$. If SDHD, SDHB and SDHC testing had negative results, then SDHAF2 mutation should be checked (101). In fact, discoveries in gene expression and the cellular pathways of PCCs will likely offer a basis for personalized medicine in near future. The presence of a germ-line mutation is possible in patients with every following feature; early onset ( $\leq 45$ years), bilateral, multifocal or extra-adrenal tumors, recurrent or malignant disease and positive family history for PCCs $(97,102)$.Genetic testing of nonsyndromic patients with apparently sporadic PCCs is dependent to histological evaluation, localization and catecholamine production (85). 
After the completion of human genome project, some epigenetic alteration of genome like methylation can be the key genetic changes leading to carcinogenesis in oncology field of study (103105). Consequently epigenetics of PCCs can shed a light on its diagnosis and prognosis the same as other tumors (106).

If we take the knowledge of liquid biopsy and modern advance molecular techniques into consideration, challenges for PCCs diagnosis, management and treatment could be solved $(12,71$, 107, 108). Interestingly in the near future it will be easily possible to analyze all PCCs related genes in only one shot using the whole-genome sequencing (109).

\section{Conclusions:}

Despite several advances in pathology and microscopic measurements of PCCs, the precise management of this tumor has not been possible yet. There is a big opportunity that genetic and epigenetic of PCCs can provide additional data about PCCs. Therefore, various indicators for the exact genetic origin possibly will be checked in advance to improve biochemical and histology testing results.

\section{Acknowledgment}

Authors acknowledge their gratitude to Endocrinology and Metabolism Population Sciences Institute, Tehran University of Medical Sciences.

\section{Conflict of Interest}

The authors declared no conflict of interest.

\section{References}

1. Boulpaep EL, Boron WF, Caplan MJ, Cantley L, Igarashi P, Aronson PS et al. Medical Physiology a Cellular and Molecular Approach. Signal Transduct 2009;48:27.

2. Beard CM, Sheps SG, Kurland LT, Carney JA, Lie JT. Occurrence of pheochromocytoma in Rochester, Minnesota, 1950 through 1979. Mayo Clin Proc 1983;58(12):802-4.

3. Haghpanah V, Soliemanpour B, Heshmat R, Mosavi-Jarrahi AR, Tavangar SM, Malekzadeh R et al. Endocrine cancer in Iran: based on cancer registry system. Indian J Cancer 2006;43(2):80-5.

4. Larijani B, Shirzad M, Mohagheghi MA, Haghpanah V, Mosavi-Jarrahi AR, Tavangar SM et al. Epidemiologic analysis of the Tehran cancer institute data system registry (TCIDSR). Asian Pac J Cancer Prev 2004;5(1):36-9.

5. Guerrero MA, Schreinemakers JM, Vriens MR, Suh I, Hwang J, Shen WT et al. Clinical spectrum of pheochromocytoma. J Am Coll Surg 2009;209(6):727-32.

6. Tsirlin A, Oo Y, Sharma R, Kansara A, Gliwa A, Banerji MA. Pheochromocytoma: a review. Maturitas 2014;77(3):229-38.

7. Lenders JW, Eisenhofer G, Mannelli M, Pacak K. Phaeochromocytoma. Lancet 2005; 366(9486):665-75.

8. Tavangar SM, Larijani B, Mahta A, Hosseini SM, Mehrazine M, Bandarian F. Craniopharyngioma: a clinicopathological study of 141 cases. Endocr Pathol 2004;15(4):339-44.

9. Tavangar SM, Shojaee A, Moradi Tabriz H, Haghpanah V, Larijani B, Heshmat R et al. Immunohistochemical expression of Ki67, c-erbB2 , and c-kit antigens in benign and malignant pheochromocytoma. Pathol Res Pract 2010 ;206(5):305-9.

10. Larijani B, Mohagheghi MA, Bastanhagh MH, Mosavi-Jarrahi AR, Haghpanah V, Tavangar $\mathrm{SM}$ et al. Primary thyroid malignancies in Tehran, Iran. Med Princ Pract 2005;14(6):396-400.

11. Larijani B, Bastanhagh $\mathrm{MH}$, Pajouhi M, Kargar Shadab F, Vasigh A, Aghakhani S. Presentation and outcome of 93 cases of craniopharyngioma. Eur J Cancer Care (Engl) 2004 ;13(1):11-5.

12. Kong A, Leboucher P, Leek R, Calleja V, Winter S, Harris A et al. Prognostic value of an activation state marker for epidermal growth factor receptor in tissue microarrays of head and neck cancer. Cancer Res 2006;66(5):2834-43.

13. Bravo EL, Tagle R. Pheochromocytoma: state-of-the-art and future prospects. Endocr Rev 2003;24(4):539-53. 
14. Smythe GA, Edwards G, Graham P, Lazarus L. Biochemical diagnosis of pheochromocytoma by simultaneous measurement of urinary excretion of epinephrine and norepinephrine. Clin Chem 1992;38(4):486-92.

15. Eisenhofer G, Timmers HJ, Lenders JW, Bornstein SR, Tiebel O, Mannelli M et al. Age at diagnosis of pheochromocytoma differs according to catecholamine phenotype and tumor location. $\mathrm{J}$ Clin Endocrinol Metab 2011;96(2):375-84.

16. Cooper ME, Goodman D, Frauman A, Jerums G, Louis WJ. Phaeochromocytoma in the elderly: a poorly recognised entity? Br Med J (Clin Res Ed) 1986;293(6560):1474-5.

17. Munakata M, Aihara A, Imai Y, Noshiro T, Ito S, Yoshinaga K. Altered sympathetic and vagal modulations of the cardiovascular system in patients with pheochromocytoma: their relations to orthostatic hypotension. Am J Hypertens 1999 ;12(6):572-80.

18. Haghpanah V, Shooshtarizadeh P, Heshmat R, Larijani B, Tavangar SM. Immunohistochemical analysis of survivin expression in thyroid follicular adenoma and carcinoma. Appl Immunohistochem Mol Morphol 2006;14(4):422-5.

19. Omidfar K, Moinfar Z, Sohi AN, Tavangar SM, Haghpanah V, Heshmat R et al. Expression of EGFRvIII in thyroid carcinoma: immunohistochemical study by camel antibodies. Immunol Invest 2009;38(2):165-80.

20. Attaran SY, Omrani GH, Tavangar SM. Lymphoepithelial-like intrathyroidal thymic carcinoma with foci of squamous differentiation. Case report. APMIS 1996;104(6):419-23.

21. Tischler AS, Kimura N, Mcnicol AM. Pathology of pheochromocytoma and extra-adrenal paraganglioma. Ann N Y Acad Sci 2006 ;1073(1):557-70.

22. Bravo EL, Tarazi RC, Gifford RW, Stewart BH. Circulating and urinary catecholamines in pheochromocytoma. Diagnostic and pathophysiologic implications. $\mathrm{N}$ Engl $\mathrm{J}$ Med 1979;301(13):682-6.
23. Rosano TG, Swift TA, Hayes LW. Advances in catecholamine and metabolite measurements for diagnosis of pheochromocytoma. Clin Chem 1991;37(10 Pt 2):1854-67.

24. Young WF Jr. Pheochromocytoma: issues in diagnosis \& treatment. Compr Ther 1997;23(5):319-26.

25. Eisenhofer G, Goldstein DS, Kopin IJ, Crout JR. Pheochromocytoma: rediscovery as a catecholamine-metabolizing tumor. Endocr Pathol 2003;14(3):193-212.

26. Gardet V, Gatta B, Simonnet G, Tabarin A, Chêne $G$, Ducassou $D$ et al. Lessons from an unpleasant surprise: a biochemical strategy for the diagnosis of pheochromocytoma. J Hypertens 2001;19(6):1029-35.

27. Gerlo EA, Sevens C. Urinary and plasma catecholamines and urinary catecholamine metabolites in pheochromocytoma: diagnostic value in 19 cases. Clin Chem 1994;40(2):250-6.

28. Guller U, Turek J, Eubanks S, Delong ER, Oertli D, Feldman JM. Detecting pheochromocytoma: defining the most sensitive test. Ann Surg 2006;243(1):102-7.

29. Lenders JW, Pacak K, Walther MM, Linehan WM, Mannelli $\mathrm{M}$, Friberg $\mathrm{P}$ et al. Biochemical diagnosis of pheochromocytoma: which test is best? JAMA 2002;287(11):1427-34.

30. van der Harst E, de Herder WW, de Krijger RR, Bruining HA, Bonjer HJ, Lamberts SW et al. The value of plasma markers for the clinical behaviour of phaeochromocytomas. Eur J Endocrinol 2002;147(1):85-94.

31. O'Connor DT, Bernstein KN. Radioimmunoassay of chromogranin A in plasma as a measure of exocytotic sympathoadrenal activity in normal subjects and patients with pheochromocytoma. N Engl J Med 1984 Sep;311(12):764-70.

32. John H, Ziegler WH, Hauri D, Jaeger P. Pheochromocytomas: can malignant potential be predicted? Urology 1999 Apr;53(4):679-83.

33. Proye CA, Vix M, Jansson S, Tisell LE, Dralle H, Hiller W. "The" pheochromocytoma: a 
benign, intra-adrenal, hypertensive, sporadic unilateral tumor. Does it exist? World J Surg 1994 Jul-Aug;18(4):467-72.

34. Eisenhofer G, Walther M, Keiser HR, Lenders JW, Friberg P, Pacak K. Plasma metanephrines: a novel and cost-effective test for pheochromocytoma. Braz J Med Biol Res 2000;33(10):1157-69.

35. Dove AE, Marathe PH, Gao HX, Close KL. American Association of Clinical Endocrinologists 2017. J Diabetes 2017. https://doi.org/10.1111/1753-0407.12573.

36. Sinclair D, Shenkin A, Lorimer AR. Normal catecholamine production in a patient with a paroxysmally secreting phaeochromocytoma. Ann Clin Biochem 1991;28(Pt 4):417-9.

37. Stewart MF, Reed P, Weinkove C, Moriarty KJ, Ralston AJ. Biochemical diagnosis of phaeochromocytoma: two instructive case reports. J Clin Pathol 1993;46(3):280-2.

38. Shawar L, Svec F. Pheochromocytoma with elevated metanephrines as the only biochemical finding. The Journal of the Louisiana State Medical Society: official organ of the Louisiana State Medical Society. 1996;148(12):535-8.

39. Lenders JW, Keiser HR, Goldstein DS, Willemsen JJ, Friberg P, Jacobs MC et al. Plasma metanephrines in the diagnosis of pheochromocytoma. Ann Intern Med 1995 Jul;123(2):101-9.

40. Elijovich F, Lenders J, Keiser H. Plasma metanephrines in the diagnosis of pheochromocytoma. Ann Intern Med 1996;124(7):694-5.

41. Salmenkivi K. Tumor Markers in Pheochromocytomas: Kaisa Salmenkivi; 2003.

42. Leibowitz-Amit R, Mete O, Asa SL, Ezzat S, Joshua AM. Malignant pheochromocytoma secreting vasoactive intestinal peptide and response to sunitinib: a case report and literature review. Endocr Pract 2014;20(8):e145-50.
43. Lauring BP, Hoda SA. Tumors of the Adrenal Gland and Extra-Adrenal Paraganglia. Arch Pathol Lab Med 1998;122(5):480.

44. Linnoila RI, Keiser HR, Steinberg SM, Lack EE. Histopathology of benign versus malignant sympathoadrenal paragangliomas: clinicopathologic study of 120 cases including unusual histologic features. Hum Pathol 1990;21(11):1168-80.

45. Unger PD, Cohen JM, Thung SN, Gordon R, Pertsemlidis D, Dikman SH. Lipid degeneration in a pheochromocytoma histologically mimicking an adrenal cortical tumor. Arch Pathol Lab Med 1990;114(8):892-4.

46. Vassallo G, Capella C, Solcia E. Grimelius' silver stain for endocrine cell granules, as shown by electron microscopy. Stain Technol 1971;46(1):713.

47. Chetty R, Clark SP, Taylor DA. Pigmented pheochromocytomas of the adrenal medulla. Hum Pathol 1993;24(4):420-3.

48. van der Harst E, Bruining HA, Jaap Bonjer $\mathrm{H}$, van der Ham F, Dinjens WN, Lamberts SW et al. Proliferative index in phaeochromocytomas: does it predict the occurrence of metastases? J Pathol 2000;191(2):175-80.

49. Mete O, Tischler AS, de Krijger R, McNicol AM, Eisenhofer G, Pacak K et al. Protocol for the examination of specimens from patients with pheochromocytomas and extra-adrenal paragangliomas. Arch Pathol Lab Med 2014;138(2):182-8.

50. Mete O, Asa SL. Endocrine Pathology with Online Resource. Cambridge University Press; 2016.

51. Thompson LD. Pheochromocytoma of the Adrenal gland Scaled Score (PASS) to separate benign from malignant neoplasms: a clinicopathologic and immunophenotypic study of 100 cases. Am J Surg Pathol 2002;26(5):551-66.

52. Srivastava A, Tischler AS, Delellis RA. Endogenous biotin staining as an artifact of antigen retrieval with automated immunostaining. Endocr Pathol 2004;15(2):175-8. 
53. Tischler AS, Tsokas P, Shahsavari M, Powers JF. Immunoreactivity of normal rabbit serum with epinephrine (E) cells of the rat adrenal medulla after microwave antigen retrieval. Cell Tissue Res 1998 ;293(3):563-6.

54. Amousha MR, Kish NS, Heshmat R, Rajabiani A, Saffar H, Haghpanah V et al. Corrigendum: Expression of the Pituitary Tumor Transforming Gene (PTTG1) in Pheochromocytoma as a Potential Marker for Distinguishing Benign Versus Malignant Tumors. Acta Med Iran 2015;53(6):392.

55. Tavangar SM, Monajemzadeh M, Larijani B, Haghpanah V. Immunohistochemical study of oestrogen receptors in 351 human thyroid glands. Singapore Med J 2007;48(8):744-7.

56. Saffar H, Sanii S, Emami B, Heshmat R, Panah VH, Azimi S et al. Evaluation of MMP2 and Caspase-3 expression in 107 cases of papillary thyroid carcinoma and its association with prognostic factors. Pathol Res Pract 2013;209(3):195-9.

57. Sarmadi S, Izadi-Mood N, Sotoudeh K, Tavangar SM. Altered PTEN expression; a diagnostic marker for differentiating normal, hyperplastic and neoplastic endometrium. Diagn Pathol 2009;4(1):41.

58. Glinicki P, Jeske W, Bednarek-Papierska L, Kasperlik-Załuska A, Rosłonowska E, GietkaCzernel $\mathrm{M}$ et al. Chromogranin A (CgA) in adrenal tumours. Endokrynol Pol 2013;64(5):358-62.

59. Jahn R, Schiebler W, Ouimet C, Greengard P. A 38,000-dalton membrane protein (p38) present in synaptic vesicles. Proc Natl Acad Sci USA 1985;82(12):4137-41.

60. Leong AS, Cooper K, Leong FJ. Manual of diagnostic antibodies for immunohistology. Cambridge University Press; 2003.

61. Wiedenmann B, Huttner WB. Synaptophysin and chromogranins/ secretogranins - widespread constituents of distinct types of neuroendocrine vesicles and new tools in tumor diagnosis. Virchows Arch B Cell Pathol Incl Mol Pathol 1989;58(2):95-121.
62. Wick MR, Scheithauer BW, Kovacs K. Neuron-specific enolase in neuroendocrine tumors of the thymus, bronchus, and skin. Am J Clin Pathol 1983;79(6):703-7.

63. Rutishauser U, Acheson A, Hall AK, Mann DM, Sunshine J. The neural cell adhesion molecule (NCAM) as a regulator of cell-cell interactions. Science 1988;240(4848):53-7.

64. Grignon DJ, Ro JY, Mackay B, Ordóñez NG, el-Naggar A, Molina TJ et al. Paraganglioma of the urinary bladder: immunohistochemical, ultrastructural, and DNA flow cytometric studies. Hum Pathol 1991;22(11):1162-9.

65. Komminoth P, De Krijger R, Tischler A. Paraganglia and the adrenal medulla. Endocrine pathology Churchill Livingstone, Philadelphia. 2002:149-69.

66. Dabbs DJ. Diagnostic immunohistochemistry: Elsevier Health Sciences; 2013.

67. Mahta A, Haghpanah V, Lashkari A, Heshmat R, Larijani B, Tavangar SM. Nonfunctioning pituitary adenoma: immunohistochemical analysis of 85 cases. Folia Neuropathol 2007;45(2):72-7.

68. Sharifi R, Allameh A, Biramijamal F, Mohammadzadeh SH, Rasmi Y, Tavangar SM et al. Relationship between genetic polymorphism of glutathione S-transferase-p1 and p53 protein accumulation in Iranian esophageal squamous cell carcinoma patients. Indian J Cancer 2008;45(1):812.

69. Kelishomi RB, Ejtemaeemehr S, Tavangar SM, Rahimian R, Mobarakeh JI, Dehpour AR. Morphine is protective against doxorubicin-induced cardiotoxicity in rat. Toxicology 2008; 243(12):96-104.

70. Momeny M, Sabourinejad Z, Zarrinrad G, Moghaddaskho F, Eyvani H, Yousefi H et al. Antitumour activity of tivozanib, a pan-inhibitor of VEGF receptors, in therapy-resistant ovarian carcinoma cells. Sci Rep 2017;7:45954.

71. Khatami F, Aghayan HR, Sanaei M, Heshmat R, Tavangar SM, Larijani B. The potential of circulating tumor cells in personalized 
management of breast cancer: A systematic review. Acta Med Iran 2017;55(3):175-93.

72. Bryant J, Farmer J, Kessler LJ, Townsend RR, Nathanson KL. Pheochromocytoma: the expanding genetic differential diagnosis. J Natl Cancer Inst 2003;95(16):1196-204.

73. Benn DE, Robinson BG. Genetic basis of phaeochromocytoma and paraganglioma. Best Pract Res Clin Endocrinol Metab 2006 ;20(3):435-50.

74. Burnichon N, Brière JJ, Libé R, Vescovo L, Rivière J, Tissier $\mathrm{F}$ et al. SDHA is a tumor suppressor gene causing paraganglioma. Hum Mol Genet 2010;19(15):3011-20.

75. Papathomas TG, Gaal J, Corssmit EP, Oudijk L, Korpershoek E, Heimdal K et al. Nonpheochromocytoma (PCC)/paraganglioma (PGL) tumors in patients with succinate dehydrogenaserelated PCC-PGL syndromes: a clinicopathological and molecular analysis. Eur J Endocrinol 2013; 170(1):1-12.

76. Assadipour Y, Sadowski SM, Alimchandani M, Quezado M, Steinberg SM, Nilubol $\mathrm{N}$ et al. SDHB mutation status and tumor size but not tumor grade are important predictors of clinical outcome in pheochromocytoma and abdominal paraganglioma. Surgery 2017;161(1):230-9.

77. Hao HX, Khalimonchuk O, Schraders M, Dephoure N, Bayley JP, Kunst H et al. SDH5, a gene required for flavination of succinate dehydrogenase, is mutated in paraganglioma. Science 2009;325(5944):1139-42.

78. Bayley JP, Kunst HP, Cascon A, Sampietro ML, Gaal J, Korpershoek E et al. SDHAF2 mutations in familial and sporadic paraganglioma and phaeochromocytoma. Lancet Oncol 2010;11(4):366-72.

79. Qin Y, Yao L, King EE, Buddavarapu K, Lenci RE, Chocron ES et al. Germline mutations in TMEM127 confer susceptibility to pheochromocytoma. Nat Genet 2010;42(3):229-33.

80. Comino-Méndez I, Gracia-Aznárez FJ, Schiavi F, Landa I, Leandro-García LJ, Letón R et al. Exome sequencing identifies MAX mutations as a cause of hereditary pheochromocytoma. Nat Genet 2011;43(7):663-7.

81. Hernandez KG, Ezzat S, Morel CF, Swallow C, Otremba M, Dickson BC et al. Familial pheochromocytoma and renal cell carcinoma syndrome: TMEM127 as a novel candidate gene for the association. Virchows Arch 2015;466(6):72732.

82. Timmers HJ, Kozupa A, Eisenhofer G, Raygada M, Adams KT, Solis D et al. Clinical presentations, biochemical phenotypes, and genotype-phenotype correlations in patients with succinate dehydrogenase subunit B-associated pheochromocytomas and paragangliomas. J Clin Endocrinol Metab 2007;92(3):779-86.

83. Amar L, Baudin E, Burnichon N, Peyrard $\mathrm{S}$, Silvera $\mathrm{S}$, Bertherat $\mathrm{J}$ et al. Succinate dehydrogenase $B$ gene mutations predict survival in patients with malignant pheochromocytomas or paragangliomas. $\mathrm{J}$ Clin Endocrinol Metab 2007;92(10):3822-8.

84. Eisenhofer G, Lenders JW, Timmers H, Mannelli M, Grebe SK, Hofbauer LC et al. Measurements of plasma methoxytyramine, normetanephrine, and metanephrine as discriminators of different hereditary forms of pheochromocytoma. Clin Chem 2011;57(3):41120.

85. Karasek D, Frysak Z, Pacak K. Genetic testing for pheochromocytoma. Curr Hypertens Rep 2010;12(6):456-64.

86. Schlisio S, Kenchappa RS, Vredeveld LC, George RE, Stewart R, Greulich H et al. The kinesin KIF1Bbeta acts downstream from EglN3 to induce apoptosis and is a potential 1p36 tumor suppressor. Genes Dev 2008;22(7):884-93.

87. Opocher G, Schiavi F. Genetics of pheochromocytomas and paragangliomas. Best Pract Res Clin Endocrinol Metab 2010;24(6):94356.

88. Welander J, Söderkvist P, Gimm O. Genetics and clinical characteristics of hereditary pheochromocytomas and paragangliomas. Endocr Relat Cancer 2011;18(6):R253-76. 
89. Dahia PL, Ross KN, Wright ME, Hayashida CY, Santagata S, Barontini M et al. A HIF $1 \alpha$ regulatory loop links hypoxia and mitochondrial signals in pheochromocytomas. PLoS Genet 2005;1(1):72-80.

90. Karasek D, Shah U, Frysak Z, Stratakis C, Pacak K. An update on the genetics of pheochromocytoma. J Hum Hypertens 2013;27(3):141-7.

91. Timmers HJ, Gimenez-Roqueplo AP, Mannelli M, Pacak K. Clinical aspects of SDHxrelated pheochromocytoma and paraganglioma. Endocr Relat Cancer 2009;16(2):391-400.

92. Petri BJ, van Eijck $\mathrm{CH}$, de Herder WW, Wagner A, de Krijger RR. Phaeochromocytomas and sympathetic paragangliomas. $\mathrm{Br} \mathrm{J}$ Surg 2009;96(12):1381-92.

93. Müller U, Troidl C, Niemann S. SDHC mutations in hereditary paraganglioma/ pheochromocytoma. Fam Cancer 2005;4(1):9-12.

94. Korpershoek E, Favier J, Gaal J, Burnichon $\mathrm{N}$, van Gessel B, Oudijk $\mathrm{L}$ et al. SDHA immunohistochemistry detects germline SDHA gene mutations in apparently sporadic paragangliomas and pheochromocytomas. J Clin Endocrinol Metab 2011 Sep;96(9):E1472-6.

95. Neumann HP, Pawlu C, Pęczkowska M, Bausch B, McWhinney SR, Muresan M et al.; European-American Paraganglioma Study Group. Distinct clinical features of paraganglioma syndromes associated with SDHB and SDHD gene mutations. JAMA 2004 Aug;292(8):943-51.

96. Jiang S, Dahia PL. Minireview: the busy road to pheochromocytomas and paragangliomas has a new member, TMEM127. Endocrinology 2011 Jun;152(6):2133-40.

97. Amar L, Bertherat J, Baudin E, Ajzenberg C, Bressac-de Paillerets B, Chabre O et al. Genetic testing in pheochromocytoma or functional paraganglioma. J Clin Oncol 2005;23(34):8812-8.

98.Gill AJ, Benn DE, Chou A, Clarkson A, Muljono A, Meyer-Rochow GY, et al. Immunohistochemistry for SDHB triages genetic testing of SDHB, SDHC, and SDHD in paraganglioma-pheochromocytoma syndromes. Human pathology. 2010;41(6):805-14.

99. van Nederveen FH, Gaal J, Favier J, Korpershoek E, Oldenburg RA, de Bruyn EM, et al. An immunohistochemical procedure to detect patients with paraganglioma and phaeochromocytoma with germline SDHB, SDHC, or SDHD gene mutations: a retrospective and prospective analysis. The lancet oncology. 2009;10(8):764-71.

100.Baysal BE, Ferrell RE, Willett-Brozick JE, Lawrence EC, Myssiorek D, Bosch A, et al. Mutations in SDHD, a mitochondrial complex II gene, in hereditary paraganglioma. Science. 2000;287(5454):848-51.

101.Hensen EF, Bayley J-P. Recent advances in the genetics of SDH-related paraganglioma and pheochromocytoma. Familial cancer. 2011;10(2):355-63.

102.Mannelli M, Castellano M, Schiavi F, Filetti S, Giacche M, Mori L, et al. Clinically guided genetic screening in a large cohort of Italian patients with pheochromocytomas and/or functional or nonfunctional paragangliomas. J Clin Endocrinol Metab 2009;94(5):1541-7.

103.Venter JC, Adams MD, Myers EW, Li PW, Mural RJ, Sutton GG, et al. The sequence of the human genome. Science. 2001;291(5507):130451 .

104.Khatami F, Noorinayer B, Mohebi SR, Ghiasi S, Mohebi R, Hashemi M, et al. Effects of amino acid substitution polymorphisms of two DNA methyltransferases on susceptibility to sporadic colorectal cancer. Asian Pac J Cancer Prev. 2009;10(6):1183-8.

105. Khatami F, Mohebi SR, Ghiasi S, Haghighi MM, Safaee A, Hashemi M, et al. Amino acid substitution polymorphisms of two DNA methyltransferases and susceptibility to sporadic colorectal cancer. Gastroenterology and Hepatology from bed to bench. 2009;1(3).

106.Mohammadi-asl J, Larijani B, Khorgami Z, Tavangar SM, Haghpanah V, Kheirollahi M, et al. Qualitative and quantitative promoter hypermethylation patterns of the P16, TSHR, 
RASSF1A and RAR $\beta 2$ genes in papillary thyroid carcinoma. Medical Oncology. 2011;28(4):1123-8.

107.Alix-Panabières C, Pantel K. Circulating tumor cells: liquid biopsy of cancer. Clinical chemistry. 2013;59(1):110-8.

108. Khatami F, Larijani B, Tavangar S.

Circulating Tumor BRAF Mutation and
Personalized Thyroid Cancer Treatment. Asian Pacific journal of cancer prevention: APJCP. 2017;18(2):293.

109. Mardis ER. The impact of next-generation sequencing technology on genetics. Trends in genetics. 2008;24(3):133-41.

\section{How to Cite This Article:}

Khatami, F., Tavangar, SM. Current Diagnostic Status of Pheochromocytomaand Future Perspective: A Mini Review. Iran J Pathol, 2017; 12(3): 324-333. 